\title{
A COMPARATIVE STUDY OF THE EFFECT OF GLOBALIZATION ON IRAN'S SOCIAL DEVELOPMENT IN TWO KHATAMI'S AND AHMADINEJAD'S ADMINISTRATIONS
}

\author{
Farzaneh Seifouri ${ }^{1}$ \\ Seyyed Amir Masoud Shahram $\mathrm{Nia}^{2}$ \\ Abbas Hatami ${ }^{3}$ \\ Seyyed Javad Emamjomeh Zadeh ${ }^{4}$
}

\section{Introduction}

The two discourses of globalization and development are structurally landmark processes in the twentieth century. But it cannot be claimed that they were prior to the twentieth century. At the same time, the belonging of these two discourses to the twentieth century cannot be construed as the end of their life and the end of their consumption history in the twenty-first century, because both processes have recently found the conditions for institutionalization. The underlying problem is that these two discourses have so far not been considered either in the cause-effect relationship or mutual influence or interaction. Based on this formulation, globalization can have different effects on different countries and even on states and administrations in a single country. The present article is to answer the question whether the policies, strategies, and performances of the two Khatami and Ahmadinejad administrations have coincided with the process of globalization and its re-

\footnotetext{
I Ph.D. student of political science, University of Isfahan. farzaneh.seifoori@gmail.com. The article has been extracted from a PhD thesis.

2 Assistant Professor of Political Science, Faculty of Law and Political Science, University of Isfahan (Corresponding Author), E-mail: m.shahramnia@ase.ui.ac.ir

3 Associate Professor of Political Science, Faculty of Law and Political Science, Isfahan University, A.hatami@ase.ui.ac.ir

4 Associate Professor of Political Science, Faculty of Law and Political Science, Isfahan University.
} 
quirements, or have maintained their own discourses while preserving relative values and ideological principles of the Islamic Revolution.

In this regard, it can be said that the administration of Seyyed Mohammad Khatami presented a policy of détente within the framework of "dignity, wisdom and expediency". This ideological phrase can be exactly seen in the 20-Year National Vision of the Islamic Republic of Iran. In other words, effective and constructive interaction with the world is based on the principles of dignity, wisdom, and expediency in this period, which of course is not independent from its other sections. The use of such terms reflects the design and implementation of Iranian foreign policies based on the independence of opinions and ideologies as well as companionship with other streams.

The Khatami administration's discourse diminished the role of the "national government" in the development process. The non-indigenous and affiliated theories and strategies were presented in this period, and many of the main issues and real problems and challenges of the Iranian society were ignored, or at least marginalized, by highlighting issues related to globalization processes; consequently, no fundamental thought was devised for them.

Eventually, the Khatami administration ended its operation in summer 2005, when Ahmadinejad came forward with another approach and policy under the title "the emergence of a national government in a time of globalization". As the president of the ninth and tenth administrations, Ahmadinejad stated his disbelief in "digestion and integration in the process of globalization"; a completely different view from the president of Iranian seventh and eighth administrations.

Ahmadinejad knew globalization generally in globalization of acculturation, imposition of literature and a particular kind of life for all nations, which ensures the continuity of domination of the whole world and the preservation of the distance between rich and poor countries, since globalization is aimed at removing the last cultural barriers of nations against the global dominant regime and the wave in the direction of the economic development program. He believed that although the stated goal of globalization had been economic expansion, it did not succumb to this goal so that it continued its direction in political development for accepting the imported pattern to affect the sovereign systems of the countries. Ahmadinejad sees today's media serving as a channel of domination.

Since Ahmadinejad believed that with the process of globalization many of the unique and rare resources in Iran have vanished, he saw the need of the Iranian society and the only way to move to the peak of perfection and real progress in the Islamic-Iranian development model. He claimed that passive movements against imported theories would never yield a satisfactory 
result. In addition to resistance to expansionist ideas, the lack of influence of government decisions in the decline of the role of the "national government" is very effective, which places Ahmadinejad in the era of globalization in the face of the process of land degradation. His views on this issue are completely different from those of Khatami as the head of the seventh and eighth administrations. Ahmadinejad considers participation in social development in the process of globalization from the origins of "Iran" and the "Iranian" base.

\section{Literature review}

The significance of reviewing literature related to a subject is to show that the present research is based on a wide range of previous studies (Sayyed Emami, 2008: 133-I37).

Globalization is a category that has attracted the minds of many scholars and experts in various economic, political and social spheres over the past few decades. The phenomenon that became apparent in the second half of the twentieth century influenced all continents in the middle of this century so that its natural process affected the advancement of communication technologies by affecting the economic, social, cultural and political dimensions, and brought about closer human beings have different kinds of differences in terms of race, nationality, skin color, and geographical boundaries.

Various resources have been written in the form of valuable books and articles translated into Persian. In the meantime, if one wants to arbitrarily make a division for the effect of globalization on development in its general form, we can mention writings of authors such as Kerry, Dunlop, Harbison, Daniel Bell, and Nicholas Lohman. Theoreticians such as Burton, Gilpin, and Rosena have addressed this issue from a political point of view. In addition, researchers such as Marshall Lohman have cultural and communicative perspectives on the issue of globalization (Mcluhan, I964: 83). Anthony Giddens (Giddens, I990: 83), Ronald Robertson, and Malcolm Waters (Robertson, I992: 92) have had independent and dynamic views on this subject, and have presented comprehensive works.

In the introduction, three important pieces of Iranian works are introduced. Thinkers such as Sari Al Ghalam (2008), in Iran and Globalization: Challenges and Solutions, examines the beliefs and bases of the political elites and the interior social-political structure via a linear-historical understanding of the issues of Iran, and investigates the process of globalization as a new stage of capitalist system in the structure of power and wealth of the international system via an analysis based on the recognition of the international 
environment of Iran.

Shahramnia (2006) in his book Globalization and Democracy in Iran, explores the effects of globalization indices on the fluctuation of democracy indices. In addition to examining the state of democracy in Iran and the conditions in Iran's transition, he investigates factors such as the status of parties, the status of the press, the way of election, and the process of decision-making, and the turn in the political power, each of which can be influenced by global factors and reflect the state of democratization of Iran.

The book Globalization: Perceptions and Reports (2003) examines different perceptions of globalization, its enormous implications in international relations and in the geographic region, including the Middle East and Iran, with specific issues such as energy and OPEC via various articles.

Dreher (2008) examines the various globalization indices from different perspectives, and points to different views on this trend.

The present study is different from other studies having done on the same subject because it examines the effect of globalization, as an independent variable and a keyword, on Iranian social development, as a dependent variable. It also undertakes an analytical research method and a causal-comparative research design for investigating how globalization affects social development in the two Khatami's and Ahmadinejad's administrations. The rationale underlying doing the research is that since it comes to assessing the degree of globalization of countries, measuring the degree of globalization with its various dimensions got more highlighted. This article tries to examine how Iran has been affected by social globalization via the comparison between the two governments in order to conclude how much the decisions and policies of governments can influence the social development path along with the globalization process.

\section{Research terminology}

Prior to entering any scientific discussion, it is necessary to define and take into consideration the research concepts (Seyyed Emami, 2008: I62) for obtaining a clear and precise understanding of the concepts used in the research. 


\section{Comparative research design}

A comparative research design can be used to study and explore varieties with a subset of similarities and differences in a given set of selected and desired items. A comparative approach is a way for descriptive or causal scientific inferences through the systematic comparison of similarities and differences in social phenomena that can be used to homogenize information and obtain comparable variables globally (Manouchehri, 2008: 256). Since the study of international issues or the topic of globalization has been considered as a topic of the day, a comparative study of it was also considered. For example, in this research, the two Khatami and Ahmadinejad governments are considering the hypothesis of globalization, based on the social development of Iran. A comparative approach is based on the comparison of two or more groups or communities and even the person subject to comparison. This comparison can be done on a specific group at different times. In this research, two governments in a society may be examined, which is called the comparative method (Saroukhani, 2006: 40). Its purpose is to compare a few of a variable in a large sample of units (Taheri, 2005: I90).

The first objective of the comparative method is to describe the political and social phenomena of a country or countries; good description is very important in this regard. The second goal of this classification method is to make the data clearer; classification can be started and conducted by criteria. For example, in the present study, globalization is seen as a criterion, and, social development are selected from among the dimensions of development to address the effect of this process on social development and make proper classification. The third goal is the comparative method is hypothesis testing, which is to be discussed via explaining and investigating of the hypothesis testing of the subject. The final goal of the comparative method is prediction. For example, in this study, with the study of social globalization, we will anticipate the impact of this trend on social development towards future governments with their social approaches. However, in many studies, prediction may not be the case. This trend is expressed in comparative strategies in terms of probabilities (Manouchehri, 2008: 26I).

This article aims to use a comparative method. In some cases of the comparative method, causal-comparative research design is used. Accordingly, considering the dependent variable, a researcher investigates the possible causes of a phenomenon with regard to its past states in order to find out its possible effects. In some cases, the causes may not be manipulative. For example, in this article, globalization is considered as an independent variable which have characteristics whose effects on such instances as development 
are often inevitable. That is, the process goes through the structure of governments. For example, in this paper, with an overview of the opportunities and constraints of the two aforementioned governments, indices and sub-indices have been examined which indicate their degree of alignment with the trend of globalization. The society has changed with these changes and social changes are seen in terms of the subject of the article in different dimensions of the people's lives. The main difference between these two approaches is in the analysis of causality between independent and dependent variables, which the researcher rejects or confirms the statistical assumptions to confirm or reject causal relationships (Taheri, 2005: I92).

This study considers a case study whose components are temporally and locally limited to two states in one country. From a local point of view, Iran and, in terms of time, two Khatami's and Ahmadinejad's administrations are examined in two trends from 1998 to 2004 and from 2004 to 2013 , respectively. Case studies in terms of time and place implies McKay and Marsh's view which does not consider the comparative method limited to the comparison of countries, but considers a small instance of the comparison in the time and place unit (McKay \& Marsh, 2005: 28I).

This style is novel in that it eventually connects somewhat between the internal and external outlook of development. Regarding the internal and external conditions of governments and their orientation in the field of foreign policy, we see some minor and sometimes important changes. These changes in the type of governments' discourse can affect national levels and social development with regard to the subject matter of the article. Accordingly, the subject of our study in this article is Iran. Social Globalization is the independent variable, and its analysis unit, i.e. social development in two Khatami's and Ahmadinejad's administrations is the dependent variable. The data of the present research has been obtained according to KOF Globalization Index.

\section{Globalization}

Globalization as an independent variable and key concept in this research is very important and has become one of the common terms in various fields.

The term "globalization" is derived from the word "globe" means Earth and the world in Latin. For the first time in the early ig6os, this term entered the literature of the day, and the Webster Dictionary put this term in its collection as an entry in I96r. This term attracted researchers' attentions as a 
scientific phenomenon since the early I990's (Akhavan Zanjani, 2007: 47).

Gradually, with the rapid advances in the field of communication and information technology, the term globalization has become increasingly important, and has entered political, economic, and sociological debates since the I980s, replacing internationalization and the of transnationalization. Globalization refers to the transformation at the level of human organization that connects distant communities and extends the scope of access to power relations across regions and continents of the world. Using the opinions of experts and the research procedure, globalization can be considered as a process based on the speed of time with an impact on the whole world, in which individuals in a single global community are spontaneously merged, resulting in the face of many geopolitical constraints along with social and cultural affiliations. Social indices of globalization can be shown as follows:

\section{Table 1: Social Indices of Globalization}

\begin{tabular}{|c|c|c|}
\hline Indexes & Dimension & Concept \\
\hline $\begin{array}{l}\text { - The fade of geographical bor- } \\
\text { ders, and the increase in the } \\
\text { interaction and communication } \\
\text { among nations; } \\
\text { - Creation of efficient and low- } \\
\text {-cost communication networks } \\
\text { at the global level; } \\
\text { - The rise in values such as libe- } \\
\text { ration, peace, security, civil socie- } \\
\text { ty, etc. via the creation of social } \\
\text { development; } \\
\text { - Creation of transnational social } \\
\text { spaces of which individuals can } \\
\text { be considered as a citizen regar- } \\
\text { dless of their nations and ethni- } \\
\text { city; } \\
\text { - Social mobilization and the de- } \\
\text { velopment of migrations at the } \\
\text { global level; } \\
\text { - More diversity in different eth- } \\
\text { nic and local groups; } \\
\text { - The increase in the speed of } \\
\text { public communication and the } \\
\text { decrease in different communi- } \\
\text { cation costs; } \\
\text { - Accessibility to a new space and } \\
\text { time towards individuals regar- } \\
\text { dless of the role of their govern- } \\
\text { ments; }\end{array}$ & Social & Globalization \\
\hline
\end{tabular}




\section{Developement}

Development, as the research dependent variable, is a modern and important concept via which the state of a society in terms of economy, the amount of inequality, the status of manpower, and the political and social status of society are measured. In addition to quantitative and qualitative goals, this concept is used to indicate the extent of progress in various economic, political and social dimensions (Culture, I992: 6I). Moreover, the development is a directional process is accompanied by the growth of self-reliance occurring within a developing community at any time and place in succession. Development is a process that can be measured via comparison. Referring experts' opinions, development can be defined as a process based on changes with quantitative and qualitative goals in the economic, political, social and cultural fields, which ultimately leads to improving individuals' quality of life in all its dimensions. Social development creates a change in the way of thinking, values, attitudes, behaviors and social roles in a society. Accordingly, social development is a process that involves the presence of citizens on the community scene to achieve collective goals. It is better in this process to combine individual needs with wider social needs and rule the society in order to portray the process of social development along with concepts such as justice, equality, and freedom. The indices of social development can be shown as follows:

\section{Table 2: Social Development Indices}

\begin{tabular}{|c|c|c|}
\hline Indexes & Dimension & Concept \\
\hline $\begin{array}{l}\text { - The rise in the level of quality of } \\
\text { healthcare and education; }\end{array}$ & \multirow{6}{*}{ Social } & \multirow{6}{*}{ Globalization } \\
\hline $\begin{array}{l}\text { - The rise in the qualitative indi- } \\
\text { ces such as social participation, } \\
\text { social integrity, and social justice; }\end{array}$ & & \\
\hline $\begin{array}{l}\text { - Gender quality in using oppor- } \\
\text { tunities and the active presence } \\
\text { of women in social fields; }\end{array}$ & & \\
\hline $\begin{array}{l}\text { - Civil activities and participation } \\
\text { as well as the state-nation rela- } \\
\text { tions at the global level; }\end{array}$ & & \\
\hline $\begin{array}{l}\text { - The increase in the trust and } \\
\text { security among citizens and cre- } \\
\text { ation of social cohesion among } \\
\text { different groups; }\end{array}$ & & \\
\hline - Integration of minorities; & & \\
\hline
\end{tabular}




\section{Seyyed Mohammad Khatami's administration}

Seyyed Mohammad Khatami has been the president and head of state in the Islamic Republic of Iran during two periods, known as the "reform government":

- The seventh government and Khatami's first administration (I997200I); 2005);

- The eighth government and Khatami's second administration (200I-

The Khatami administration refers to the two presidential terms of Seyyed Mohammad Khatami, which includes the seventh and eighth states of the Islamic Republic of Iran. During this period, the reformist faction had the full power of Iran's executive branch, which lasted from August 3, I997 to August 3, 2005. Khatami's administrations described their main motto as political development and the strengthening of civil institutions.

The beginning of Khatami's administration led to a decline in oil prices and a decline in foreign exchange earnings to 9.9 billion\$. Borrowing from the central bank to close the budget deficit led to an increase in inflation by more than 20 percent in 1378 , which gradually fell by about 13 percent. At that time, the government implemented a currency exchange policy that was successful. Economic growth helped reduce debt by more than 6 percent. The particular government's approach to domestic and foreign developments has led to events that include: creating a more open political and press space in society and universities, a serious transformation of foreign relations, especially with European countries, chain killings, September II events, the events of July I8, I999, the US invasion of Afghanistan and the US invasion of Iraq, the holding of the first election of the Islamic councils of the city and the village after the revolution, recording the record for the most economic growth among the Islamic republics, the successful implementation of lowering the inflation rate and bringing it to I०\%, and successful implementation of single exchange rate.

\section{Mahmoud Ahmadinejad's administration}

Mahmoud Ahmadinejad has been the president and head of state in the Islamic Republic of Iran during two periods:

- The ninth government and Ahmadinejad's first administration (2005-2009); 
- The tenth government and Ahmadinejad's second administration (2009-2013);

The presidency of Mahmoud Ahmadinejad began on August 3, 2005, and he became the sixth President of the Islamic Republic of Iran. Ahmadinejad had been the mayor of Tehran at the time of the victory over Akbar Hashemi Rafsanjani in the Iranian presidential election in 2005. Ahmadinejad won the second term of presidency after the Iranian presidential election in 2009 by defeating rivals like Mir Hossein Mousavi, Mehdi Karroubi and Mohsen Rezai. The specific government's approach towards domestic and foreign developments has led to events that include: dissatisfaction with the structure of the international system and the attempt to reform and change this structure, implementation of public diplomacy in foreign policy, coherence and progress in the Iranian nuclear energy program, disclosure of the nature of the Holocaust, the plan of early-stage companies, the economic development plan, and the Mehr housing plan.

\section{Globalization and the policies in Khatami's and Ahmadinejad's administrations}

\section{Socialpolitical polices of Khatami's administration in relation with globalization}

The election of Seyyed Mohammad Khatami on May 23, I997, with a large number of Iranian votes, accounts for about $70 \%$ of the total vote, as an important political phenomenon, raised wonders among many analysts and observers. Khatami's declared domestic policies include: the rule of law; respect for the rights and freedoms of the people, namely civil society; the elimination of social discrimination; tolerance; the maintenance of human dignity; the establishment of social security; the continuation of economic reconstruction of the country; the declaration of the rule of law; the accountability of the government to the people; the freedom of criticism; collective unity; national unity; political development; and support for the formation of political parties. Meanwhile, the international challenges of Iran, such as opening criminal and terrorist cases against the Islamic Republic of Iran in Western courts, Iran's condemnation in some of these trials (such as Mikonos, Germany); reduction in the level of relations between developed countries and Iran; repeated and effective allegations about Iran's interference in the domestic affairs of other countries; the scare of small countries in the region for Iran's expansionist intentions; violent tone of propaganda against Iran and vice ver- 
sa; expanded convictions against the Islamic Republic of Iran in international organizations; and the rising risk of economic activity in Iran in the most critical and poorest countries in the world; etc. are some aspects of the situation of the Islamic Republic of Iran in 1996 and early I 997 at the international level among others. Slowness, downturn, and even darkness in relations with some Islamic countries, such as some the Persian Gulf states, Algeria, Egypt, Turkey, etc., blurry relations with all European countries, especially Germany, Britain, France, Norway, Austria, the coldness of relations with other advanced countries, such as Japan, or even the blurring of relations with remote countries such as Argentina, the relative coldness of relations with some friends which had the relative agreement with Iran regarding not supporting Iran were parts of problems for Iranian foreign policy in early I997 (Aminzadeh, 200I: 9I). Accordingly, one can mention the most important policies that Khatami has taken in his administration and some kind of political development in Iran both in domestic and foreign affairs: foreign policy based on the dialogue of civilizations and the promotion of the dignity of Iran at the international level, the policy of détente in the framework of dignity, wisdom and expediency, foreign policy based on the expansion of relations with all countries of the world, the transformation of Iran from an isolated actor to a fully active and positive, promotion of activities of parties in terms of social development, government, the promotion of the press and the provision of an open space for the expression of ideas and views, the generation of civil society literature, and the growth of political culture among others.

\section{Sociopolitical policies of Ahmadinejad's administration in relation with globalization}

During the two presidential terms, Mahmoud Ahmadinejad took over Iranian highest executive position. The ninth state of the Islamic Republic of Iran came about as a result of Mahmoud Ahmadinejad's victory in the June 24, 2004 election. The President's validation was carried out by Ayatollah Khamenei, the leader of the Islamic Revolution on August 3, 2005. The government officially commenced on August I2, 2005, and ended on August I2, when the tenth government began.

On August I6, 2005, Ahmadinejad announced the full text of his government plan. He called his government "a Merciful State" or "State of Mercy".

The tenth government of the Islamic Republic of Iran came about as a result of Mahmoud Ahmadinejad's victory in the June I2, 2009 elections. The president's validation was held by the Supreme Leader of the Islamic 
Revolution Ayatollah Khamenei on August 3 and his inauguration was held in the Islamic Consultative Assembly on August 5th. The government did its tasks from August 3, 2009 to August 3, 2013 when it was replaced by Hassan Rouhani's administration.

The political policy of the Ahmadinejad's government in the domestic and international arena was based on principles such as dissatisfaction with the structure of the international system and efforts to reform and change this structure, domination of the idealistic discourse principles based on foreign policy of the Islamic Republic of Iran, reliance on public diplomacy, the use of national power of undeveloped or developing countries in the face of the great powers. In terms of social development, his government declared concepts based on justice in the form of indigenous development based on indigenous ideas about social development in order to plan for the administration of Iran and solve people's problems. Relying on the government and national identity, he wanted to advance real democracy.

In this regard, we want to see how far Iran's rapid confrontation with the new developments in the world and the two governments, i.e. the Khatami and Ahmadinejad administrations with the elite collection and their political-social system, have been able to achieve or even distance themselves from desirability. Referring to internal examples of social development and the globalization process, we review the statistical measures of social globalization in this regard.

\section{Statistical survey of social globalization towards social development in the Khatami's and Ahmadinejad's administrations using data obtained from the website < https:// www.kof.ethz.ch>}

The process of globalization as an inclusive process with a different impact on different countries, evaluated the extent of globalization with regard to the varying influence of different countries on this trend in global studies. Although different countries may have similar or different performances regarding this process, the aim of this article is to examine the role of two different governments, as the research dependent variable, in the process of globalization, as an independent variable. To examine the similar or different performance of both Khatami's and Ahmadinejad's governments regarding Iran's social development, such as the study of countries, one can use a statistical source to compare the growth and fluctuation of social indices with respect to the comparison of two states in a country. 
For the statistical survey of the three resources of A. T. Kearney Index (200I), Maastricht (2002) and the KOF Globalization Index since 2002 are available. Although the he website https://www.kof.ethz.ch firstly presented the data from 2002 onwards to the public, later it made the data from I970 onwards (Dreher, 2006: 4-5).

In the early 200I, the A. T. Kearney Index, by the famous "Foreign Policy" and "Kearney International Counseling Office", for the first time, defined the combination of this process for the first time with respect to the multi-dimensional components of globalization. Accordingly, the ranking of countries in the world is economically, politically and culturally consistent with globalization was done. Maastricht measured political, military, social, communications, and environmental indices in relation to the globalization process (Dreher, 2008: 32). The KOF Globalization Index also examines three of economic, political and social dimensions, whose hypotheses are described in Dreher, Gaston, and Martens (2008). Norris, Kohan and Nay defined the KOF Globalization Index as the process of creating a network of interconnection among actors in intercontinental distances with regard to the three of economic, political and social dimensions which appears in a wide and diverse range of movements including people, information and beliefs, capital, and services (Clark, 2000: I08-86). The KOF Globalization Index has always been a continuation of the statistical measurement of indices and, with the availability of past statistics since I970, widened the temporal horizons. The further it has come, the more the number of countries has become, so that it almost has examined 200 countries and has made it available in a wide range of statistical surveys. As a result, a comparative study of countries and even governments within a country is possible in the form of a case study.

The data of KOF Globalization Index has measured the social globalization index through three sub-indices of Personal Contact, Information Flows, and Cultural Proximity. Each of these sub-indices has been evaluated as an item in terms of smaller indexes and variables. The sub-index of personal contact is measured in terms of indices such as international telephone traffic, trancfers (percent of GDP), international tourism, foreign population (percent of total population) and international letters (per capita). the data on the information flow is analyzed and measured in terms of indices such as the amount of internet use per I,००० people, internet users (per Ioo० people), cable television (per Iooo people), trade in newspapers (percent of GDP), and the use of radio (per Iooo people). Finally, the data on cultural proximity is measured via the number of McDonald's restaurants (per capital), and trade in books (percent of GDP).

The KOF Index converts each of the variables to an index ranging 
from I-IO०: the highest value for each variable is as IO०, and I represents the lowest value. This collected data is compiled annually at the end of each year. To measure the calculation of the numerical equation is used:

$$
\frac{\mathrm{Vi}-\mathrm{V}_{\min }}{\mathrm{V}_{\min }-\mathrm{V}_{\min }} \times 10
$$

Vi is the variable value for country $i$, vmax is the highest value of the variable among countries, vmin represents the lowest value among countries (Dreher,2008:45). The figure shows the extent of social globalization with regard to the subject of this paper and its effects on the social development process of both Khatami's and Ahmadinejad's administrations .

\section{The status of globalization in Khatami's administration}

First, we examine the status of social globalization, personal contact, information flow, and cultural proximity in Khatami's government. The index of social globalization in Khatami's government in 1997 was as $20.76 \%$, in I998 as $21.99 \%$, in I999 as $23.31 \%$, in 2000 as $24.57 \%$, in 200 I as $24.81 \%$, in 2002 as $27.29 \%$, in 2003 as $28.12 \%$, and in 2004 as $29.62 \%$. The index of social globalization in Khatami's government from 1997 to 2004 was $8.86 \%$. This index had been increasing over the 8-year term of Khatami's government (Figure I).

Figure 1 - Source: www.globalization.ethz.ch

The KOF Globalization Index in Khatami's Administration

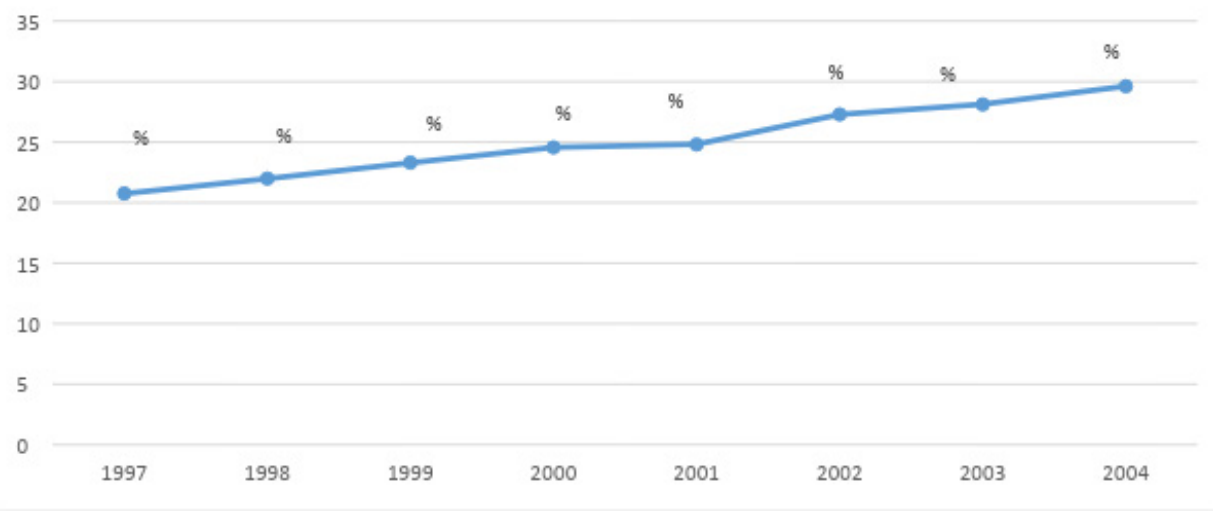




\section{Personal contacts in Khatami's government}

Personal contact is one of the sub-indices of social globalization. This sub-index in Khatami's government in I997 was as $28.12 \%$, in I998 as $27.94 \%$, in I999 as $28.25 \%$, in 2000 as $28.33 \%$, in 200 I as $28.13 \%$, in 2002 as $28.45 \%$, in 2003 as $28.26 \%$, and in 2004 as $28.57 \%$. The values show that the sub-index of personal interaction in Khatami's government decreased as I8\% from 1997 to I998. The trend shows an increase as $38 \%$ from 1998 to I999. But it represents a decrease as I9\% with fluctuations in 2000; however, again in 2002, it shows a $32 \%$ increase, but in 2003 , the trend shows a $19 \%$ decrease, and again in 2004, it displays a 31\% increase. Values show that the index of personal contact in Khatami's government has an intermittently decreasing and increasing trend. Considering this fluctuation, the index of personal contact in Khatami's government increased by 7I\% (Figure I-I).

Figure 1-1 - Source: www.globalization.ethz.ch

Personal contact in Khatami's administrtation

29

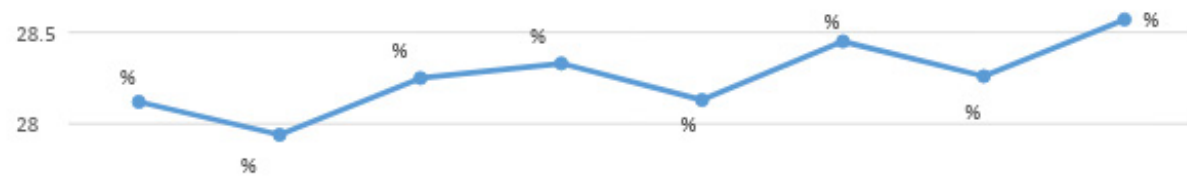

27.5

27

$\begin{array}{llllllll}1997 & 1998 & 1999 & 2000 & 2001 & 2002 & 2003 & 2004\end{array}$

Information flow in Khatami's administration

The second suboindex of social globalization is information flow which was as $31.15 \%$ in Khatami's government in $1997,34.49 \%$ in 1998 , $38.49 \%$ in I999, 4 I.06 in $2000,42.15 \%$ in 2001 , 49.18 in $2002,52.07$ in 2003 , and 55.83 in 2004 . Values show that the information flow over the course of 8 years, the Khatami administration has had a dramatic growth rate as $24.78 \%$ (Figure I-2). 
Figure 1-2 - Source: www.globalization.ethz.ch

Infromation flow in Khatami's administration

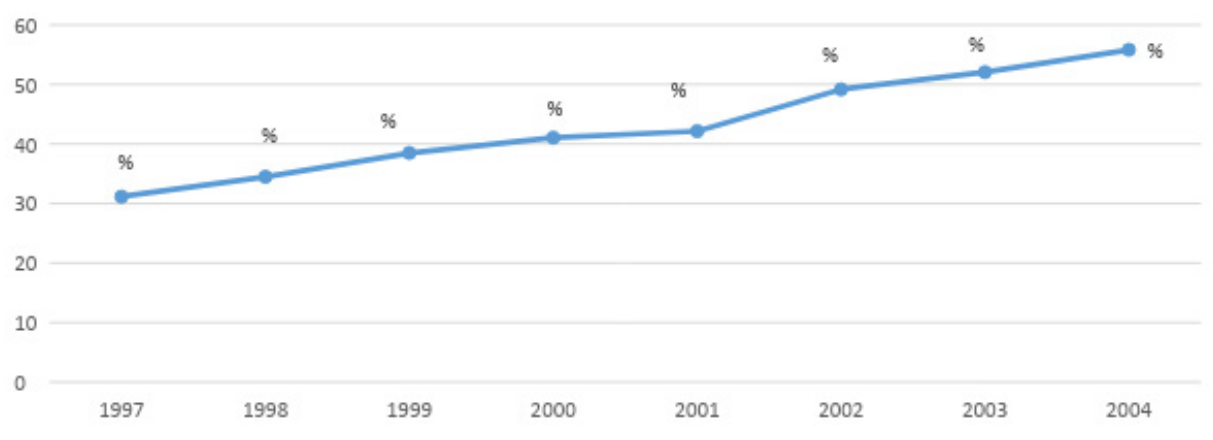

\section{Cultural proximity in Khatami's administration}

Cultural proximity is the last sub-index of social globalization, which was as I.43\% in the Khatami government in I997, I.74\% in I998, I.I2 in I999, 2.11 in 2000 , I.86 in 2001, I.49 in 2002, I.06 in 2003, and I.25 in 2004. Percentages show that the statistics related to cultural proximity in Khatami's government in 1997 and 1998 decreased by 31\%. But in I999, the trend decreases by $62 \%$, and in 1999 it had a dramatic $99 \%$ growth rate. By the end of 2003, it experienced a downtrend by I.05\%. Again, in 2004, it was up by $19 \%$.

Considering the fluctuations, if the first year of Khatami's government as I.43\% is compared to the last year of his administration in 2004 as I.25\%, then this sub-index has had a downtrend as I8\%. Values indicate that the cultural proximity index has fluctuated in Khatami's government in 8 years (Fig. I-3).

Figure 1-3 - Source: www.globalization.ethz.ch

cultural proximity in Khatami's administration

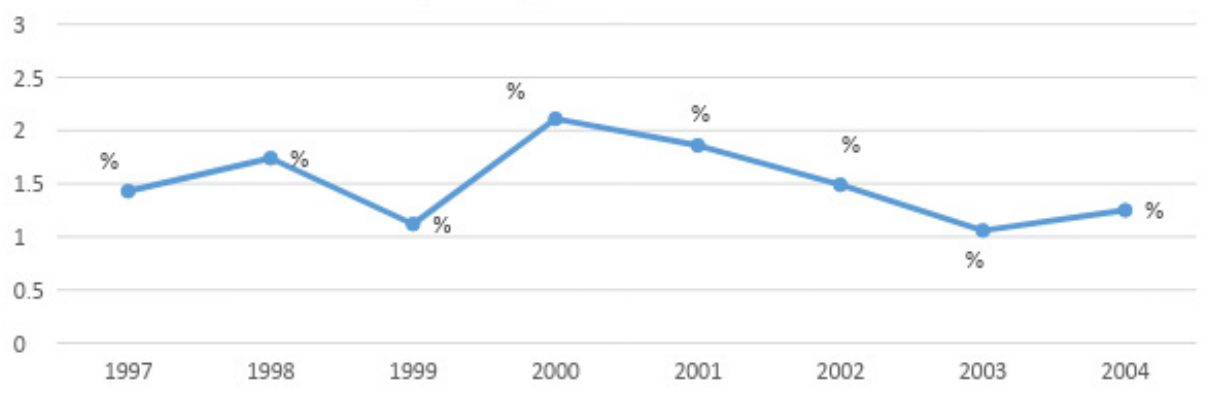




\section{The social globalization index in Ahmadinejad's administration}

The social globalization index in the Ahmadinejad administration covers years ranging from 2005 (1384), 2006, 2007, 2008, 2009, 20I0, 20II, 20I2. For investigating Ahmadinejad's administration, as for Khatami's, we first begin with a survey of the social globalization index, and then its sub-indices, i.e. personal contact, information flow, and cultural proximity are probed.

\section{The status of social globalization in Ahmadinejad's administration}

The index of social globalization in Ahmadinejad's administration was as $29.52 \%$ in $2005,30.44 \%$ in $2006,31.48 \%$ in $2007,32.65 \%$ in 2008 , 34.13 in $2009,34.82$ in 20IO, 34.63 in 201 I, and 34.40 in 2012 . Percentages show that the social globalization index in Ahmadinejad's government rose by $5.30 \%$ from 2005 to 2010 . But from 201 I to the end of 2012 , it fell by $42 \%$. Statistics also shows that the index has fluctuated in Ahmadinejad's government (Figure 2).

Figure 2 - Source: www.globalization.ethz.ch

social globalization in Ahmadinejad's administration

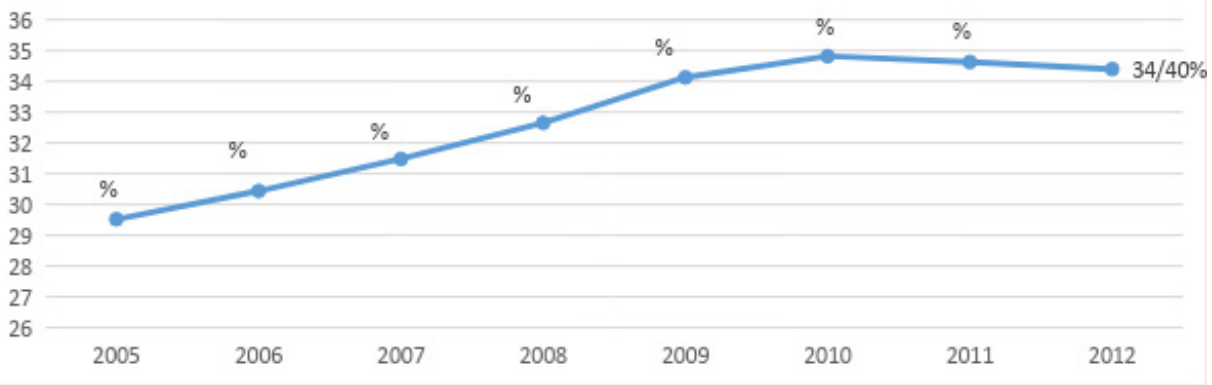

Personal contact in Ahmadinejad's administration

The index of personal contact as the first sub-index of social globalization in Ahmadinejad's government was 29.34 in 2005, 30.I2 in 2006, 3I.I3 in 2007, 3I.4I in 2008, 3I.93 in 2009, 3I.70 in 2010, 3I.I8 in 20II, and 29.72\% in 20I2. Percentages shows that the sub-index of personal contact in the Ahmadinejad government, increased by $2.59 \%$ from 2005 to 2009 , but it decreases by $2.21 \%$ from 2009 to the end of 2012 . Statistics also shows that this sub-index has fluctuated during the Ahmadinejad administration (Figure 2-I). 
Figure 2-1 - Source: www.globalization.ethz.ch

personal contact in Ahmadinejad's administration

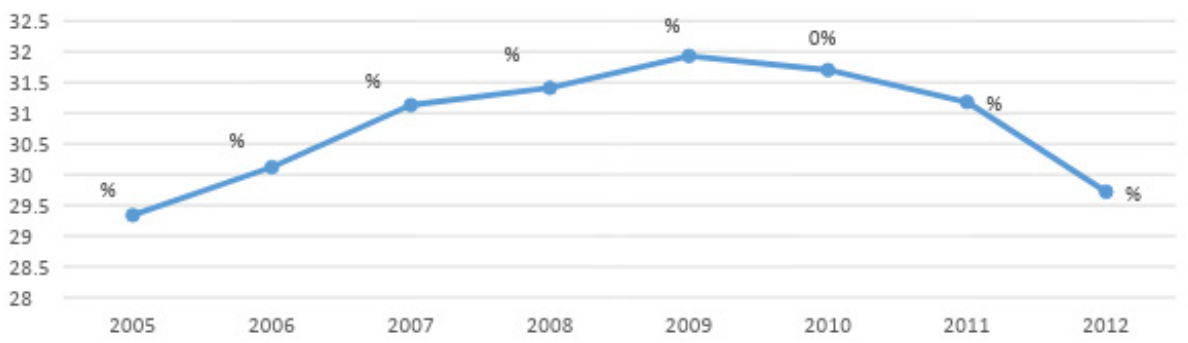

Information flow in Ahmadinejad's administration

Information flow as the second sub-index of social globalization in Ahmadinejad's government was 55.02 in $2005,56.93$ in $2006,58.86$ in 2007 , 61.90 in $2008,65.60$ in $2009,67.76$ in $2010,67.63$ in 2011 , and $68.36 \%$ in 20I2. Statistics shows that the information flow from the year 2005 to the end of 2010 was I $2.74 \%$. In 20II, this index fell by I3\%, but it rose by $73 \%$ in 2012 . Regarding the fluctuations in this sub-index, it had an uptrend as $13.47 \%$ over the eight year term of Ahmadinejad's government. (Figure 2-2).

Figure 2-2 - Source: www.globalization.ethz.ch

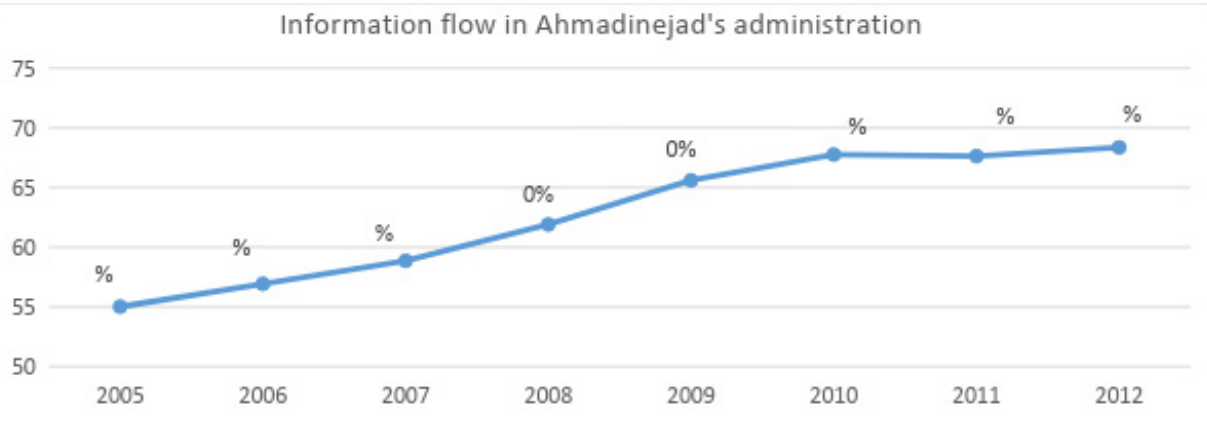

Cultural proximity in Ahmadinejad's administration

Cultural proximity as the third sub-index of social globalization in Ahmadinejad's government was 1.06 in 2005 , 1.00 in 2006, 1.06 in 2007, 1.06 in 2008 , I.06 in 2009 , I.06 in 20IO, I.I2 in 2011 , and I.I2 in 20I2. The values shows that the cultural proximity sub-index in Ahmadinejad's administration 
had a $6 \%$ downward trend from 2005 to the end of 2006 . But it rose by $6 \%$ in 2007 and was constant until the end of 2010 . In 2011 , it went up by $6 \%$ remained constant in 20I2. If we compare 2005 to 2012 , then the sub-index increased by $6 \%$. The percentages indicate that this sub-index did not have a significant change over the course of 8 years (Figure 2-3).

Figure 2-3 - Source: www.globalization.ethz.ch

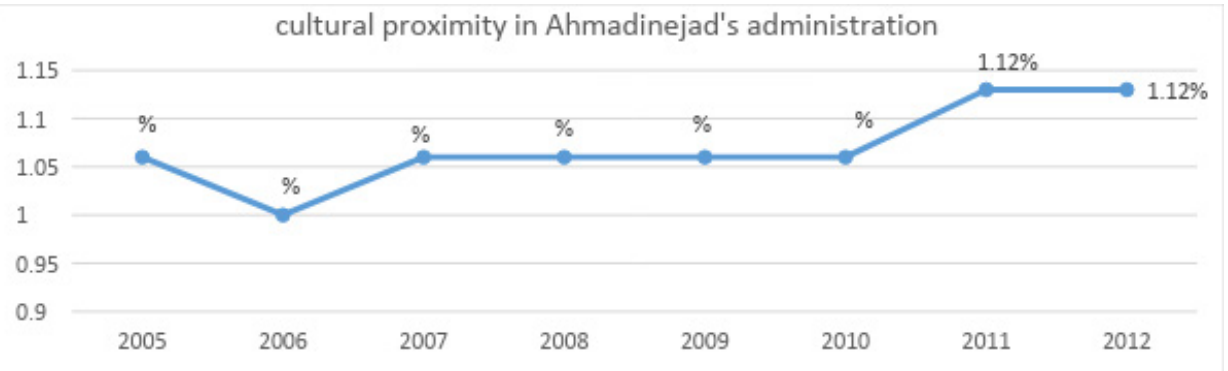

\section{Comparative investigation of social globalization indices in the two Khatami's and Ahmadinejad's administrations}

Investigating the social globalization indices in the present study covers 1997 to 2004 in Khatami's government, and from 2005 to 2012 in Ahmadinejad's government. For the annual comparison of the two governments in terms of quantitative data, Khatami's first year of presidency, i.e. 1997, is compared to Ahmadinejad's in 2005, Khatami's government in I998 to Ahmadinejad's in 2007, Khatami's government in 2000 to Ahmadinejad's in 2008, Khatami's government in 200 to Ahmadinejad's in 2009, Khatami's government in 2002 to Ahmadinejad's in 2010, Khatami's government in 2003 to Ahmadinejad's in 20II, and Khatami's government in 2004 to Ahmadinejad's in $20 \mathrm{I} 2$.

\section{Comparison of Social Globalization in Two Khatami and Ahmadine- jad Governments}

The social globalization indices in the Khatami government from 1997 to the end of 2004 , i.e. during the 8 years, had an uptrend as $8.86 \%$. The index in the Ahmadinejad government rose by $5.30 \%$ from 2005 to 2010 , but by the end of 2012 , it experienced a $42 \%$ downtrend. Therefore, the growth trend of this index in Ahmadinejad's government has fluctuated compared to 
that of Khatami's government (figure 3).

Figure 3 - Source: www.globalization.ethz.ch

comparative chart of Social Globalization Index in Khatami's and Ahmadinejad's administrations

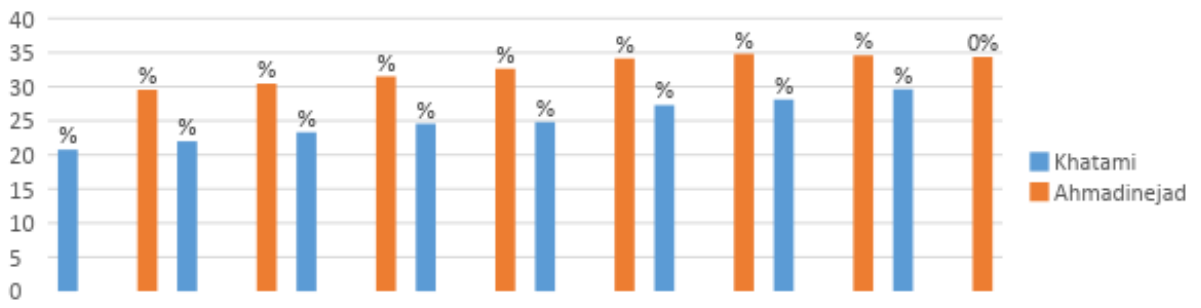

1997200519982006199920072000200820012009200220102003201120042012

\section{Comparison of personal contact in Khatami's and Ahmadinejad's administrations}

The sub-index of personal contact in Khatami's government rose from $28.12 \%$ in 1997 to $28.57 \%$ at the end of 2004 . The trend of this sub-index in the Khatami government was in fluctuation so that in his 8 year term of presidency, it rose by $7 \mathrm{I} \%$. This sub-index in the Ahmadinejad government rose by $2.59 \%$ from 2005 to the end of 2009 , but declined to $2.21 \%$ by the end of 2012 (Figure 3-I).

Figure 3-1 - Source: www.globalization.ethz.ch comparative chart of the personal contact sub-index in Khatami's and Ahmadinejad's administrations

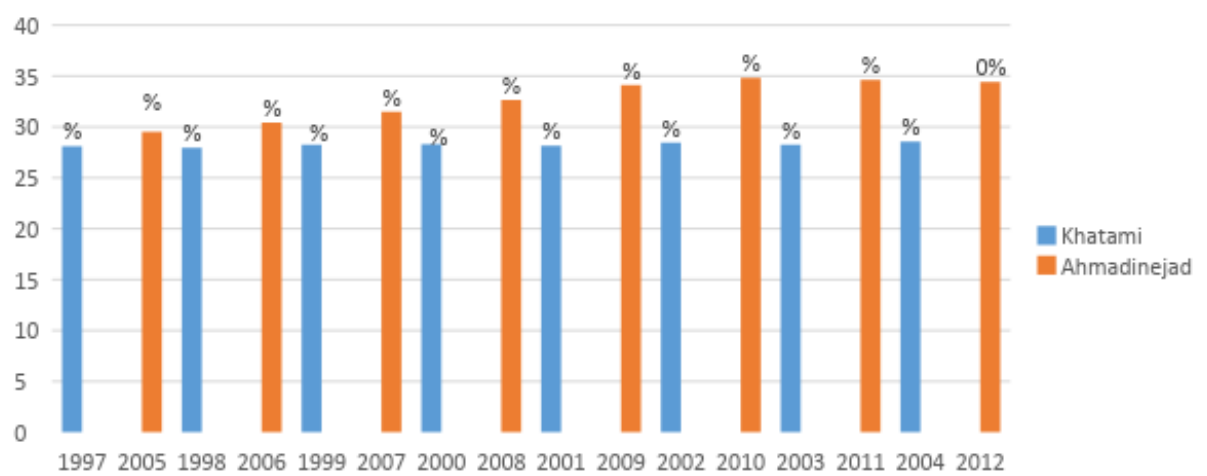




\section{Comparison of information flow in Khatami's and Ahmadinejad's administrations}

Following the information flow index in Khatami's government rose from 3 I.I5\% in I997 to $55.83 \%$ at the end of 2004 . This sub-index in the Khatami government has risen by $24 / 78 \%$ for Khatami's 8 year administration. This sub-index in Ahmadinejad's government rose from $55.02 \%$ in 2005 to $68.36 \%$ in 2012. It had an uptrend in Ahmadinejad's government over the 8 year term of presidency and obtained a $13.47 \%$ growth. In other words, the index experienced a slower uptrend in Ahmadinejad's administration than Khatami's (Figure 3-2).

Figure 3-2 - Source: www.globalization.ethz.ch

comparative chart of the Information flow sub-index in Khatami's and Ahmadinejad's administrations

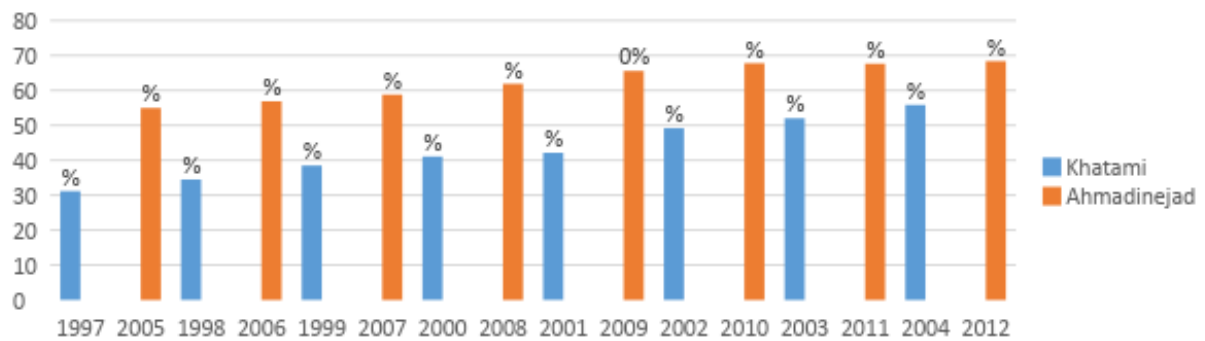

\section{Comparison of cultural proximity in Khatami's and Ahmadinejad's administrations}

The cultural proximity sub-index in the Khatami government rose from I.43 in 1997 to I.74\% in I998, namely, it experienced a 31\% uptrend. But by the end of 1999 , the index had a $62 \%$ downturn. Again, it rose by $99 \%$ in 2000 . As Figure $3-3$ shows, this sub-index again rose by 1.05\% in 2003 , and I9\% in 2004. On the other hand, the sub-index trend in the Ahmadinejad government fell by $6 \%$ from 2005 to the end of 2006 . In contrast to the first year of Khatami's government, this sub-index experienced a downtrend. In 2007 , the trend rose by $6 \%$. However, by the end of 2010 , the value remains constant, and in 20II, and it rose by $6 \%$ in 20II. By the end of 20I2, the trend value remains a constant. Lastly, this sub-index in the Ahmadinejad government grew I2\% over the 8 year term. The status of the cultural proximity sub-index was higher in the Khatami administration than Ahmadinejad's (Figure 3-3). 
Figure 3-3 - Source: www.globalization.ethz.ch

comparative chart of the cultrual proximity sub-index in Khatami's and

Ahmadinejad's administrations

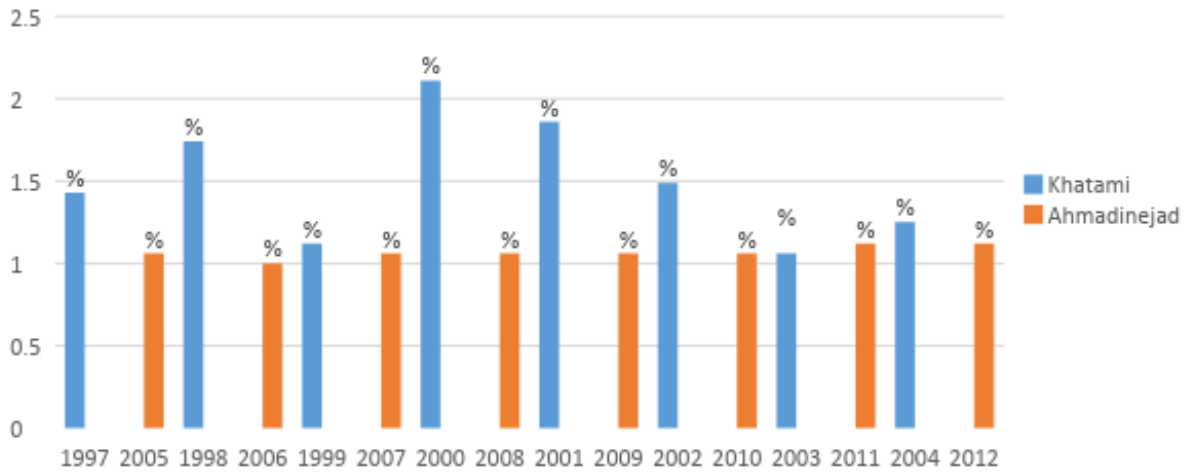

\section{Explaining the Analysis of the Performance of Two Khatami's and Ahmadinejad's Administrations in Accordance with the Process of Social Globalization with an Emphasis on Similar- ity and Differentiation}

The present paper examines the two governments' responses to the globalization process, with an emphasis on their similarity and differentiation via a comparative approach. What can be the main points of similarity and distinction? The ascending and descending trends of social indices of globalization are indicative of the good or weak performance of the ruling state in the context of social development in line with the globalization process. Khatami's government and Ahmadinejad's government both have grown up in terms of the social globalization indices and sub-indices of personal contact, information flow, and cultural proximity, and their growth rate was fluctuated in some years (Figures 3-I, 3-2, 3-3).

According to the statistics, in terms of the similarities of both governments, uptrends can be observed in their globalization process, while both governments have experienced an incremental growth trend (Chart I-I and I-3 in Khatami's government, and 2, 2-I in Ahmadinejad's). Despite the different statistics and percentages, each one has an uptrend in relation to the social globalization process. Since Ahmadinejad' second term of presidency was drawn to globalization and, in this regard, became more flexible in this direction. Statistics indicates that the type of government is related to the process 
of globalization. Despite the great differentiation between the two governments, both in terms of the variable of social globalization and its sub-indices, they have experienced growth or even fluctuation in some of the sub-indices; however, the uptrend in Ahmadinejad's government is slow. Other similarity points can be seen from the uptrend of both governments relative to the information flow that, without any fluctuations, both moved upwardly. The uptrend in the first five years of both governments was slow, but after that, the uptrend became quicker with the difference that it was more dramatic in Khatami's government (Figure I-I and 2-2). This difference can be attributed to the performance of the two governments in the domestic and international environment and the conditions governing the political-social environment of the states.

In terms of the differences, the trend of the globalization index and its sub-indices in both governments, is different and the pace of growth in Khatami's government is higher than Ahmadinejad's. For example, the trend of social globalization index in the Khatami government has been on the rise, but it was fluctuated in Ahmadinejad's government in 2OII and 20I2. It should be noted that the trend was not fallen below the level of the previous government, but its pace became slower (Chart I and 2).

Another distinction is that Khatami's government has experienced more fluctuations regarding the sub-index of personal contact than the Ahmadinejad government, but the Ahmadinejad government has faced some fluctuations in the last two years (Figure I-I and I-2 ). Regarding the cultural proximity sub-index, Khatami's government has also fluctuated, while Ahmadinejad's government experienced a downtrend in its second year that is after it experienced a 6\% uptrend, and in the seventh year, it face another 6\% uptrend. Another difference in terms of this sub-index is that Khatami's government dropped in the eighth year compared to its first year. But this case did not happen in Ahmadinejad's government (Figures I/3 and 2/3).

According to the research hypothesis, both governments have been growing according to the credible world statistics in terms of the social globalization index, with the difference that Khatami's social development coincided with the global reform, while Ahmadinejad stepped up with the emphasis on indigenous and local thoughts on social development. Comparisons show that the difference in social globalization can depend on the attitudes and practices of governments in the domestic and international environment. For example, Khatami took on a globalist worldview of the international arena and put forward the thesis of the dialogue of civilizations in the international policies, and furthered this competition with more interactions. In other words, Khatami's attempt to make social development indigenous rather than 
exogenous. On the other hand, Ahmadinejad, with an emphasis on indigenous thoughts in the first round of his government, made social development without a globalization approach, and made many efforts for social development, removal of poverty, unemployment and social harm. Consequently, Compared to Khatami's government, Ahmadinejad's government was indigenous rather than exogenous; thus it became less competitive in the globalization trend. Globalization indices in the government has had a slower pace for eight years of Ahmadinejad's government. The issue worthy of noting is that this statistics does not fall below the level of the previous government rises. Different statistics related to the governments emphasize that despite their differences in their approaches towards domestic and foreign environments, they were both in line with globalization.

\section{Conclusion}

The present study is a comparative research that examines the effect of the trend of globalization on social development as fundamental concepts in political sociology for comparing political systems in Iran in the form of two Khatami's and Ahmadinejad's governments with a desirable structure. The comparative study on the issue of globalization and development in this paper shows that these two can be mutually influential and there is a significant relationship between development and globalization, since there can be no connection between the domestic and foreign environments. By examining the performance of the two governments in Iran, we concluded that the performance of governments in the context of globalization could be different. Therefore, in addition to comparing countries in terms of the globalization process, it is possible to compare governments within a country which adopt different approaches to the globalization process. As the comparative study showed, the social globalization index was $8.86 \%$ in Khatami's government over 8 years of presidency, and dropped by $4.89 \%$ in the Ahmadinejad government over an 8-year term of presidency. This difference in governments' performance can add to the significance of the domestic structure of a country and the governments' different approaches to the globalization process. The growth of social globalization confirms the research hypothesis of the paper claiming that the social development grew in both governments, with the difference that social development in Khatami's government was based on global reforms, while it was based on indigenous and local thought in Ahmadinejad's. In addition, both governments have been affected by the varying degrees and percentages in terms of the social globalization index as the dependent variable and its sub-indices. Thus, as a comparison, it can be accept- 
ed that social globalization varies from one government to another. The degree of social globalization index can be affected by the domestic and foreign environments in which governments played a major role as players in this regard. For example, Khatami's government had more convergence with the process of globalization, and this affected the relative growth of social globalization and its sub-indices in Khatami's government. This case study conducted on Iran and the comparison of the two governments to the globalization approach showed that although the process of globalization emphasizes the interaction and interconnection of the domestic and foreign environments of countries, it is often not just dependent on the government, and can come from forms, shapes, spaces, unequal geography, etc.

The comparative investigation done on the globalization process points out that globalization, in addition to the governments' approaches, can be a function of a wide range, called the domestic environment of a society, since it implies a model of generalized political and social development. Therefore, each country chooses and follows paths to political and social development according to its political and social conditions. This is the domestic environment we emphasize and it is definitely different from one country to another. It can even affect the governments' attitude towards globalization with regard to the major differences in views towards development. But it seems important to keep moving forward. Khatami, for example, went on to advance social development with the approach of reform and global reform, while Ahmadinejad, acting on local and local thoughts on social development, proceeded. According to this approach, the uptrend in Khatami's government is higher than that of Ahmadinejad's government in terms of the social globalization index and its sub-indices.

Ultimately, this article emphasizes with the consideration and comparison of the differences in approaches to the "nature of the government in the Islamic Republic of Iran." Because governments in the Islamic Republic of Iran, both fundamentalist and reformist ones, take steps that are naturally along with globalization. The government in the Islamic Republic of Iran accepts or refuses to accept globalization, depending on its nature. Moreover, since Ahmadinejad emphasized more on indigenous and national efforts in his development, the statistics of social globalization had a slower growth trend. It is important to note that this growth did not fall, but it was slow in Ahmadinejad's government. By examining the process of social globalization on social development over the decades coinciding with the performance of two Khatami and Ahmadinejad governments, it can be said that this process has contributed to the growth of social development, and has led to the continuation of it in a roughly different way from Other countries have provided 
Farzaneh Seifouri, Seyyed Amir Masoud Shahram Nia, Abbas Hatami, Seyyed Javad Emamjomeh Zadeh

Iran. It is important that there is a conscious approach to this trend so that its strengths can be enjoyed and its weaknesses easily rejected. 


\section{REFERENCES}

Abdollahi, A. (2009). The Position of Iran in the Process of Globalization. Quarterly of Political and Economic Information. Tehran, Etela'at Publication.

Akhavan Zanjani, D. (2007). Globalization and Foreign Policy. Tehran: Knowledge Publication.

Aminzadeh, M. (2005). Political Development. Tehran. Journal of Political and Economic Information, No. II7-II8.

Bashriya, H. (200I). Lessons from Democracy for All. Tehran: Contemporary View Publication.

Clark, W. C. (2000). Environmental globalization, in: J. S. Nye \& J. D. Donahue (Eds.), Governance in globalizing world. Washington: Brookings Institution Press.

Dreher A. (2008). Noel Gaston and Pim Martens: Measuring Globalization-Gauging is consequence. New York: Mc Milan.

Giddens, A. (1990). The consequences of modernity. Cambridge: Cambridge University Press.

Giddens, A. (I999). Politics, sociology and social theory. M. Saboori (Trans.). Tehran: Nei Publication.

Globalization.Kof.ethz.ch.

McKay, T. \& Marsh, D. (2005). The Comparative Method, in: David Mears and Jerry Stoker (Eds.), Methodology and Theory in Political Science. A. M. Haji Yousefi (Trans.). Tehran: Strategic Studies Publishing House.

Mcluhan, M. (I964). Understanding media. London: Routledge.

Sariol Ghalam, M. (2008). Iran and globalization: Challenges and solutions. Tehran: Publication of the Strategic Research Center.

Robertson, R. (200I). Globalization, Global Social and Cultural Theories. K. Pouladi (Trans.). Tehran: Sales Publication.

Rosentone, J. S. \& Hansen, J. M. (I992). Mobilization, participation and democracy in America. New York: Mc Millan.

Sajjadpour, S. M. K. (2003). Globalization: Perceptions and consequences. Tehran: Office of Political and International Studies.

Saroukhani, B. (2006). Research Methods in Social Sciences. Tehran: Etela'at Publication.

Sayyadi, A. (2005). Islamic Revolution and challenges of globalization of culture. Tehran: Nikan Publication. 
Sayyed Emami, K. (2008). Political science research, economic interpretative probabilistic approaches. Tehran: Hormoz Publication.

Shahram Nia, S. A. M. (2006). Globalization and democracy. Tehran: Contemporary View Publication.

Taheri, A. (2005). Research methodology in political science. Tehran: Ghomes Publication.

http: Globalization.kof.ethz.ch. 


\section{ABSTRACT}

Globalization and social development, as two independent and interactional discourses, have been investigated in this paper using the globalization indicators in two Khatami's and Ahmadinejad's administrations. Thus, the independent variable of globalization, and the dependent variable of the state of social development of Iran are compared in the two periods of $1997-2005$ and 2005-2013 considering the different approaches adopted in the two administrations. The research method is comparative. The research hypothesis is that based on valid statistics, both administrations have been on the path to social development, but Khatami's approach was based on global reformism, and Ahmadinejad's approach was based on indigenous and local thoughts. In terms of theoretical foundations, we have used the generalization model of political-social development. According to this model, development priorities are different in countries with different political and social contexts. Social globalization grew as much as 8.86 in the Khatami's administration, and up to 4.89 in Ahmadinejad's administration. Therefore, the administration type is related to the extent of globalization, and globalization has contributed to the growth and development of social development. It also has provided a platform for the continuation of studies of this trend in a different way, regarding the states and the internal environment of the countries.

\section{KEYWORDS}

Globalization, Social Development, Global Reforms and Indigenous Thought, Khatami's Government, Ahmadinejad's Government.

Received on September 13, 2018 Approved on February 2, 2019 